Revista Bioética

\title{
PESQUISA
}

\section{Ethical and legal analysis of scientific research on corpses in Brazil}

Patricia Melo Bezerra ${ }^{1}$, Marina de Neiva Borba ${ }^{2}$, Iara Coelho Zito Guerriero ${ }^{1}$, Sueli Gandolfi Dallari ${ }^{2}$

1. Departamento de Pós-Graduação e Pesquisa, Faculdade de Medicina do ABC, Santo André/SP, Brasil. 2. Núcleo de Estudos e Pesquisas em Direito Sanitário, Universidade de São Paulo, São Paulo/SP, Brasil.

\begin{abstract}
Currently there is an increasing interest in publications on the use of corpses for research in Brazil and worldwide. Scientific evidence reveal that these studies have little ethical and regulatory control. In Brazil, the regulation of this subject is scarce and scattered among laws and sublegal normative acts, hindering the knowledge of ethical and legal practices adopted by researchers. This article analyzes the laws and norms for scientific research on corpses in Brazil through a corpus that underlies this type of research. From the 1940-2012 period, we found seven documents of the Brazilian legislation that gather information for ethical and clear research. Finally, we present guidelines and a protocol to be followed by researchers for the development of ethical and legal studies with corpses in Brazil.

Keywords: Cadaver. Research. Records. Ethics, research. Legislation. Jurisprudence.

\section{Resumo}

\section{Análise ética e jurídica da pesquisa científica sobre cadáveres no Brasil}

Atualmente há crescente interesse em publicações sobre o uso de cadáveres para pesquisa no Brasil e no mundo. Evidências científicas revelam que esses estudos têm pouco controle ético e regulatório. No Brasil, a normalização do assunto é escassa e dispersa entre leis e atos jurídicos sublegais, o que dificulta o conhecimento das práticas éticas dos pesquisadores. Este artigo analisa leis e normas de pesquisa científica sobre cadáveres no Brasil utilizando corpus documental subjacente a esse tipo de estudo. Entre 1940 e 2012, foram encontrados sete documentos na legislação brasileira que reuniam informações para pesquisas éticas e claras. Por fim, são apresentados diretrizes e protocolos que devem ser seguidos por pesquisadores em estudos éticos e legais com corpos humanos no Brasil. Palavras-chave: Cadáver. Pesquisa. Registros. Ética em pesquisa. Legislação. Jurisprudência.
\end{abstract}

\section{Resumen}

\section{Análisis ético y legal de la investigación científica con cadáveres en Brasil}

En Brasil y en todo el mundo se observa actualmente un interés creciente por las publicaciones sobre el uso de cadáveres para la investigación. Sin embargo, evidencias científicas revelan que estos estudios tienen poco control ético y regulatorio. En Brasil, la normalización del tema es escasa y dispersa entre leyes y actos jurídicos sublegales, lo que dificulta el conocimiento de las prácticas éticas entre los investigadores. El presente artículo analiza leyes y normas para la investigación científica sobre cadáveres en Brasil utilizando el corpus documental que sustenta este tipo de estudios. Se encontraron siete documentos de la legislación, publicados entre 1940 y 2012, que recopilan información para una investigación ética y clara. Con base en el análisis de estos textos, se presentan pautas y protocolos que deben seguir los investigadores en estudios éticos y legales con cuerpos humanos en Brasil. Palabras clave: Cadáver. Investigación. Registros. Ética en investigación. Legislación. Jurisprudencia. 
Since the emergence of ancient Greece medicine in the 3rd century $\mathrm{BC}$, human corpses have been used as a tool for teaching anatomy ${ }^{1}$. Rock paintings describing anatomy were found in Australia, and anatomical studies were discovered in Persian paintings ${ }^{2}$. However, during the Middle Ages, the dissection of human corpses was culturally interpreted as profanation and consequently forbidden in Europe ${ }^{3}$. Although often attributed to the Canon Law, the sacralization of dead human bodies started in the Roman society, in which the deceased relative was regarded as a protection deity of the family asset ${ }^{4}$.

With the Scientific Renaissance in the early 14th century, the use of human corpses for dissection practices became a core part of anatomy teaching in some European medical schools ${ }^{1}$. Dissection was historically related to the application of capital sentence and was performed on the corpses of executed criminals ${ }^{5}$.

In the middle of the 16th century, formal sessions of dissection assumed a public character at the university and were attended by large audiences throughout Europe. Thus, the demand for corpses for research purposes increased considerably ${ }^{1}$. Faced with an insufficient corpse supply, their illegal acquisition through thefts in wakes and cemeteries became a common practice, even among surgeons and anatomists ${ }^{6}$.

In response to the strong public outcry against these illicit practices, during the 18th and 19th centuries many European countries legalized the acquisition of corpses unclaimed by relatives, especially of black and poor people, for anatomical studies in medical schools ${ }^{6}$. Among these laws, the Anatomy Act 1832, approved by the British
Government, prohibited the use of corpses of convicted criminals and allowed cadaver voluntary donation. This law set the beginning of a paradigm shift in the corpse acquisition for anatomical dissection, according to human rights and dignity. Since then, the use of human bodies for studies and research in medical schools in most countries was feasible by voluntary donation or unclaimed corpses $^{1}$.

Although anatomical studies on cadavers have been carried out since Antiquity, a recent search for publications conducted on December 2017 in the Web of Science database, using the Medical Subject Headings "cadaver or corpse and research", showed a growing interest in this topic from 2006 to 2016 (Figure 1). While in the year 2006107 publications were indexed in the Web of Science, for 2016 we found 214 , a growth of $100 \%$.

Despite the increasing number of worldwide publications on cadaver research and the scientific progress that they promote, Bach ${ }^{7}$ warns of the poor ethical or regulatory supervising of such studies, whose lack of control allows ethically questionable practices. In this sense, in an extensive review of scientific articles about the subject published between January 2011 and December 2015, Gürses and collaborators ${ }^{8}$ found that $45.6 \%$ of them did not mention the source of samples, whereas $26.2 \%$ stated the consent for research, and only $32.4 \%$ reported some form of ethical approval for the study. Considering the need to maintain a clear and reliable relationship between anatomists and society ${ }^{8}$, it is difficult to know if these studies were conducted in an ethical and legal context due to the lack of appropriate information.

Figure 1. Number of citations of the terms "cadaver or corpse and research" in scientific articles from 2006 to 2016

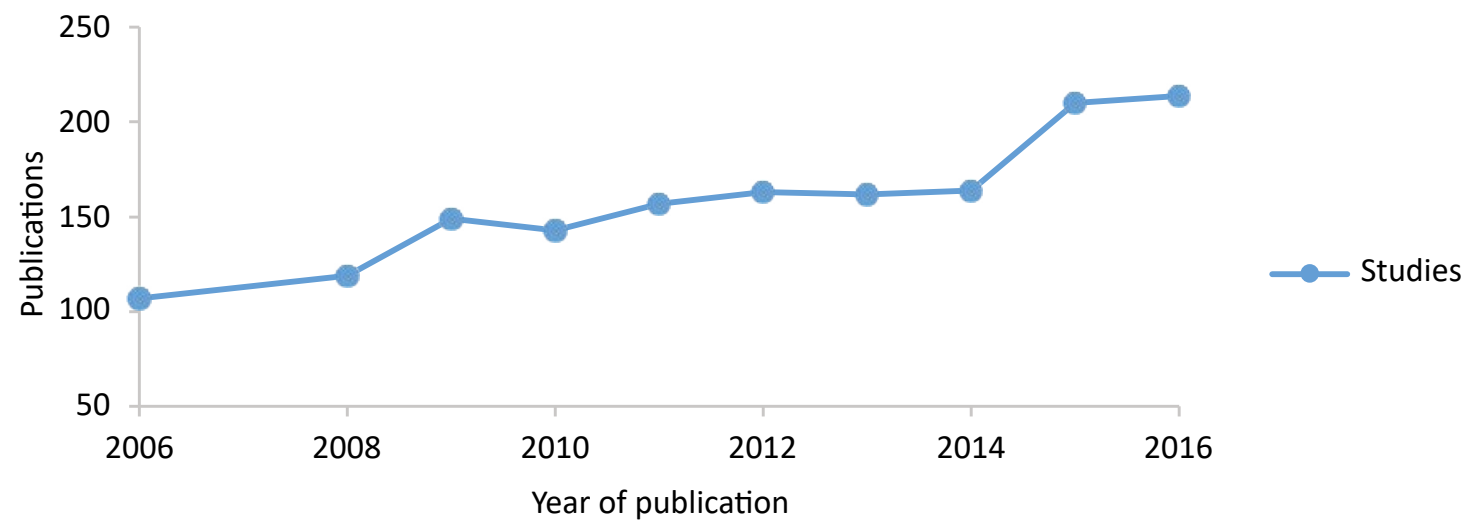


In addition, searching the Web of Science database in 2017, we found that Portuguese is the fifth most used language in the number of citations, and that Brazil occupies the eighth place in the quantity of publications on the subject. However, despite the amount of studies, the research regulations for human corpses in Brazil are still scarce and scattered among sub-legal laws and acts, hindering the implementation of ethical and legal practices. In this context, we conducted a documentary analysis of the Brazilian legislation on cadaver research, presenting guiding principles and a protocol for ethical and clear investigations on this subject.

\section{Method}

The wealth of information resulting from the analysis warrants its use in several areas of knowledge, since it increases the understanding of the research objects and identifies factual data from the questions and hypotheses of interest ${ }^{9}$. To answer them, the researcher should: 1) use appropriate techniques for handling and analyzing documents; 2) follow steps and procedures and categorize information; and 3) summarize the data to be analyzed ${ }^{10}$. The corpus of this study, collected in December 2017, consists of laws, resolutions, and responses from medical professors in relation to the corpse's rights and to guidelines and prohibitions for their use in scientific research.

Resolutions $1 / 1988^{11}$ and $196 / 1996^{12}$ of the Brazilian National Health Council (CNS) were excluded from the analysis, but the Penal Code of $1940^{13}$, the Constitution of the Federative Republic of Brazil of $1988^{14}$, Law 8,501/1992 ${ }^{15}$, the 2002 Civil Code $^{16}$, the CNS Resolution 466/2012 ${ }^{17}$, the Cadernos de Ética em Pesquisa - edited by the National Commission for Research Ethics (Conep) ${ }^{18}$-, and the provisions of the Judicial Administrative Department of São Paulo State $(\mathrm{CG} / \mathrm{SP})^{19}$. We found no guidelines of the National Council of Justice (CNJ).

At the first stage of analysis, these documents were evaluated for relevance, credibility and legal and bioethical representation, considering the following aspects: 1 ) context; 2) authors; 3) authenticity and reliability of the article; 4) article content; and 5) key concepts and internal logic of the articles ${ }^{20}$. These aspects were interpreted and summarized to guide researchers in scientific investigations using corpses in a legal, clear and ethical way, according to the legislation and technical guidelines of the medical autopsy and research ethics.
In this article, the corpus was limited to documents of national scope due to their relevance and pertinence, and did not consider state documents from forensic medicine institutes or death notification services. Moreover, due to the absence of specific legislation, there are still some concerns about the ethical and legal legitimacy of the use of corpses of neonates, children and pregnant women in Brazil. This legal gap was also highlighted in the CNS Resolution $1 / 1988^{11}$, Chapter V, which referred the need for appropriate regulation.

\section{Ethical and legal analysis for searches on corpses}

This research analyzed seven documents that were in force from 1940 to 2012 and were formulated by political authorities, health professionals, scientists and representatives of the democratic Brazilian society. Its credibility and representativeness rely on the Brazilian Constitution of $1988^{14}$, laws approved by Brazil's National Congress and other documents that are supported by universal ethical and juridical principles built in democratic spaces with transparency and citizens' participation. Our findings are entirely supported by documentary research sources and organized hierarchically from general to most specific norms.

\section{Constitution of the Federative Republic of Brazil of 1988}

Approved on October 5, 1988, the Brazilian Constitution ${ }^{14}$ is a milestone in the country's re-democratization process after 21 years of military regime. In November 1986, general elections were held, and some sectors defended the creation of an exclusive constituent assembly composed of elected representatives with the sole aim of establishing the country's new constitution. However, the proposal of the constituent congress was maintained, that is, the federal deputies and senators elected in November 1986 would also have the functions of congressmen and constituents.

The constituent assembly was finally settled in the National Congress on February 1st, 1987, with deputies and senators elected by the population. This assembly made the fundamental and sovereign Brazilian laws that serve as a foundation for all other types of regulations at the apex of the legal system ${ }^{21}$. The promulgation of the Brazilian Constitution was the result of intense discussions, conflicts, impasses, and negotiations enabled by the debate of major 
national problems and the legitimate interests of each social class ${ }^{22}$ to the whole society, as stated by Tancredo Neves. This was possible due to the movement triggered by organized sectors of the civil society that launched a national movement for the constituent assembly and, after its spreading throughout the country, due to the plenary for popular participation ${ }^{22}$.

Influenced by a scenario of re-democratization, freedom in a broad sense and popular participation, articles that guarantee the right to freedom of scientific expression were also included in the Constitution ${ }^{14}$, as in its article 5, item IX. They establish the State's duty to promote scientific and technological development (art. 218) through the Brazilian Unified Health System (art. 200, item V) and various levels of the educational system (art. 214, item V) ${ }^{14}$.

Regarding the possibility of donating human organs and tissues, including corpses, for research purposes, paragraph 4 of article 199 of the Constitution ${ }^{14}$ has delegated such regulation to the Law, highlighting the prohibition of all types of trade. In this sense, Law 8,501/1992 determined the use of unclaimed corpses for scientific studies or research ${ }^{15}$ and Law 9,434/1997 the removal of organs, tissues and parts of the human body for transplantation and treatment ${ }^{23}$. The systematic reading of these regulations shows that the development of scientific research in Brazil is constitutionally supported by the right to freedom of scientific expression, as these activities, including research, are an intellectual exercise ${ }^{24}$ protected by the Constitution and based on the freedom of teaching and research ${ }^{25}$.

\section{Penal Code of 1940}

Until the proclamation of the Republic on November 15, 1889, cemeteries represented almost sacred sites because of the religious character of the Brazilian State at the time. However, Decree $789^{26}$, proclaimed on September 27, 1890, established the secularization of graveyards by transferring their administration to the cities without the intervention of any religious authority.

Although the Penal Code of $1830^{27}$ dealt with offenses against the Catholics (art. 276 to 278), the specific penal authority for dead people appeared only with the Penal Code of $1890^{28}$. The code provided penalties for corpse burial or exhumation in disagreement with sanitary regulations (art. 364), corpse desecration and burial violation (art. 365), and damage to mausoleums or other funerary artifacts (art. 366) ${ }^{28}$.
The Penal Code of $1940^{13}$, still in force, condemns impediments or disturbances in funeral ceremonies (art. 209), burial violation (art. 210), corpse destruction, subtraction or concealment (art. 211), and corpse vilification (art. 212) as crimes. Corpse burial or exhumation disregarding legal provisions remained a criminal contravention (art. 67 of the Decree-Law 3,688/1941 ${ }^{29}$ ).

Hugo Nigro Mazzilli ${ }^{30}$ clarifies that the legal object is protected by the feeling of respect for dead persons, an ethical and social value that the law regards beyond religion. Therefore, to be a crime, it is not necessary to consider the dead person's or their relative's religion. On the other hand, Nelson Hungria ${ }^{31}$ considers that the crime against the dead person has religious nature, referring to the two chapters of the Criminal Code under the title "On the crimes against religious feeling and against respect for the dead". In both cases, all relevant ethical and social values are protected: the religious feeling and the veneration for the dead.

However, a third line of thought refutes the possibility of protecting ethical and social values by criminal laws. It considers that the dignity of the person extended after death is the true legal asset protected. According to Décio Franco David, Franco and Silva pointed out that the corpse is the existence projection of the human being, and the dignity of the dead person is the primary and permanent object of authority against acts of disrespect to human remains and graves ${ }^{32}$.

From this point of view, David ${ }^{33}$ states that death does not end all expressions of dignity contained in a person's life. Thus, the use of corpses in scientific research should imply an attitude of deference and respect for the dead person, either because of the protection of ethical and social feelings or his dignity, under the penalty of crime configuration, whose court sentences vary from one month to three years of prison to a fine payment.

\section{Civil Code of 2002}

Established by Law 10,406/2002, the Brazilian Civil Code refers to the validity of the gratuitous disposition of one's own whole corpse or its parts for scientific or altruistic purposes (art. 14, caput) ${ }^{16}$; therefore, this legal instrument is applicable to body donation for scientific research purposes. The sole paragraph of this article also ensures the free revocation at any time of this disposition. The "gratuitous character" referred to in the caput 
reveals the altruistic or scientific purpose of the act, forbidding any lucrative or commercial interest.

By representing the last will of the person, this intent of donation of one's own body for scientific purposes after death is referred in art. 1,857, §2, of the Civil Code as testamentary dispositions of non-patrimonial character, whose validity persists even if the testator is only limited to them ${ }^{16}$. But this disposition of the own body must be decided by a civilly capable person, in terms of the caput of art. 1,857 , and substantiated by a public or private instrument - in the latter case, accompanied by the signature of two witnesses, as similarly provided in Statement 37 of the $\mathrm{CNJ}^{34}$ and in art. 29, paragraph 3, of Decree $9,175 / 2017^{35}$. In this sense, the Brazilian Society of Anatomy ${ }^{36}$ published on its website a model for a document called "Statement of intent of body donation for study and research purposes".

Although the will signed in public or private instruments is not enough for body donation - the family consent is also needed ${ }^{36}-$, the doctrine of Brazilian Civil Law consolidated the understanding in $2006^{37}$. The express statement of the donor when alive regarding the donation of the whole body or its parts prevails over the family consent, being restricted to the hypothesis of silence of the potential donor.

However, Law 9,434/1997 ${ }^{23}$ requires the consent of the family of the deceased. Pimentel, Sarsur and Dadalto ${ }^{38}$ suggest the need to update the organ transplantation law, including in its text the prevalence of the donor's will, even in the face of refusal by their relatives. An amendment is currently being discussed in the National Congress for changes in this law (Bill 3,643/2019 ${ }^{39}$ ).

Finally, the sole paragraph of art. 12 of the Civil Code recognized the personality rights of the dead person ${ }^{40}$, which consist of expressions of the tutelage ${ }^{41}$, whose normative recognition is made by civil legislators ${ }^{42}$. Among the personality rights are, for example, the rights to the physical integrity of either the living or dead body and to moral integrity (honor, privacy, intimacy etc.) ${ }^{43}$.

Thus, the death of the body is not the end of the exercise of personality rights ${ }^{44}$, as provided in the sole paragraph of art. 12 of the Civil Code ${ }^{16}$, which foresees the legitimacy of the spouse or relative to judicially demand the end of the injury or threat of injury to the personality rights of the deceased, as well as to claim damages.

In this sense, from the social point of view, dead persons continue to be relevant as they survive in the memory of their relatives and of those who continue to be influenced by their legacy ${ }^{30}$. From an ethical point of view, the deceased can be regarded as subjects of rights on the ethical basis that legitimates personality rights ${ }^{45}$. Thus, the denial of these rights disrespects the dignity of the person themselves ${ }^{44}$.

In light of the above, the use of corpses in studies is based on the act of free disposition of the body for scientific purposes, substantiated by the statement of intent made by the person when alive or by the donation by relatives. In addition, considering the continuity of personality rights after death, the manipulation of the body must contemplate certain considerations, such as the physical and moral integrity of the cadaver.

\section{Law 8,501 of 1992}

Resulting from the law proposal 398 of 1989, by Senator Leite Chaves, the Federal Law $8,501^{15}$ of November 30, 1992 provides for the use of unclaimed corpses for scientific studies or research. According to its article 2, a cadaver not claimed within 30 days, that is, not identified (art. 3, item I) or not sought by relatives or legal guardians (art. 3 , item II) with the public authorities, might be assigned to medical schools for research purposes ${ }^{15}$. When there is evidence that the death resulted from criminal activity, paragraph 3 of article 3 prohibits the destination for teaching and studies.

The institutions responsible for guarding the corpse shall maintain, in accordance with article 3 , paragraph 4, information that allows the recognition of the dead person, such as photos, fingerprint sheets, necropsy results for cases in which the death resulted from an unnatural cause, allowing family members access to the data at any time (art. 5) ${ }^{15}$. Finally, the death should be published in widecirculation newspapers for at least ten days (art. 3, paragraph 1) before releasing the corpse to medical schools. Particularly, the provisions of the Judicial Administrative Department regulate the remaining concerns regarding the use of corpses for this purpose at the state level.

\section{Resolution 466/2012 of the National Health Council}

After the implementation of the new constitutional order in 1988, the CNS issued Resolution $1 / 1988^{11}$, which approved health research standards and presented the main international ethical documents among other legal bases. Its Chapter V stated that abortions and stillbirth products should comply with specific legislation that has not 
been edited to date. Likewise, as the research on corpses and human parts foreseen in Chapter VII, this decision referred to the observance of specific regulations that were subsequently elaborated.

As this document ${ }^{11}$ had little practical impact, in 1995 the CNS created a multidisciplinary executive working group (GET), bringing together physicians, nurses, theologians, engineers, members of the pharmaceutical industry, dentists and representatives of the health system users to review such research norms ${ }^{46}$. Coordinated by Professor William Saad Hossne ${ }^{47}$, the GET drafted the resolution minutes and analyzed the contributions received for six months of lectures, seminars, and meetings. Finally, in October 1996, the GET approved Resolution $196^{12}$, revoking the CNS Resolution $1 / 1988^{11}$ and creating a national system composed of local Research Ethics Committees (CEP) and the Conep ${ }^{47}$, with the participation of a multidisciplinary team and representatives of the health system users ${ }^{12,48}$. According to CNS data ${ }^{49}$, there are currently 832 CEPs registered in the Council's website, a national and unified database of records of research protocols involving human beings submitted to the CEP/Conep system.

Regarding the use of corpses for research purposes, Resolution 196/1996 ${ }^{12}$ established the requirements for conducting studies on people diagnosed with brain death, strictly meeting the following conditions: a document attesting brain death (death certificate); explicit consent of the family and/or legal guardians, or previous statement of the will; full respect for the dignity without mutilation or violation of the body; absence of additional economic/financial burden to the family; absence of prejudice toward other patients awaiting hospitalization or treatment; and possibility of acquiring relevant and new scientific knowledge that cannot be obtained otherwise.

Among these requirements is the statement of intent from the donor or the authorization for body donation by family members and/or legal representatives. Thereafter, the consent of the person himself or his relative/legal representative is enough to authorize the donation, according to the Civil Code ${ }^{16}$. Furthermore, the full respect for the person's dignity without mutilation or violation of the body ${ }^{12}$ that this resolution proclaims in its item IV.3, clause d, is in accordance with the personality rights of the dead person established by the Brazilian Civil Code ${ }^{16}$, as well as with the legal asset of dignity protected by the Brazilian Penal Code ${ }^{13}$.

In 2012, CNS Resolution 196/1996 ${ }^{12}$ was replaced by CNS Resolution $466 / 2012^{17}$, maintaining similar requirements for conducting research in people diagnosed with brain death. In addition, scientific research on corpses should, therefore, be in alignment with the other ethical standards of CNS Resolution 466/2012 ${ }^{17}$, which do not differentiate the treatment between animate and inanimate bodies.

\section{Provisions of the Judicial Administrative Department}

In order to rationalize and discipline the extrajudicial activity of notary offices, the Judicial Administrative Department of each state edit provisions that regulate the exercise of notary and registry services. Among other norms, such provisions of the courts of justice govern the use of corpses for studies and research at the state level, normalizing the practical features not contemplated by Law 8,501/1992 ${ }^{15}$. Therefore, researchers should comply with the provision of the Judicial Administrative Department of the state court of justice to which the corpse will be donated in order to follow the procedures regarding death registrations, since there are no national guidelines from the CNJ.

São Paulo has the largest number of medical schools in Brazil and the largest university hospital ${ }^{50}$, thus the provisions of the courts of justice of São Paulo are relevant for this study. In that state, for example, the death register is required for using corpses in studies (chapter XVII, item 96.1), and the medical schools must request this document to the civil registry of natural persons (chapter XVII, item 96.2) ${ }^{19}$. After that, the notary offices shall issue edicts with identification details of the corpse for the publication in wide-circulation newspapers, during ten alternate days for a 30-day period, in order to allow relatives or representatives to claim the body (chapter XVII, item 96.3) ${ }^{19}$.

Once this issuance and respective publications are proven, the documents will be referred to the judge of the Judicial Administrative Department, who will consider any claims received and decide on the authorization for the death certificate, stating the corpse specific destination (chapter XVII, item 96.4) ${ }^{19}$. The statement of intent of the person or the authorization of relatives for body donation exempts the expedition and publication of edicts (chapter XVII, item 96.5) ${ }^{19}$. After the death register, the burial or cremation of the corpse previously used in teaching and research activities shall be reported to the civil notary office for the respective registration (chapter XVII, item 96.6) ${ }^{19}$. 


\section{Expert's response to the Conep query}

The CNS Resolution 196/1996 ${ }^{12}$ (subsequently replaced by $466 / 2012^{17}$ ) foresaw the possibility that the CEP request consultations to experts in the area of which they want to obtain technical information (item VII.14, clause b). Based on the difficulties of implementing CEPs in different regions of the country and the need to disseminate the successful experiences, Conep edited the journal Cadernos de Ética em Pesquisa ${ }^{18}$ from 1998 to 2005, in which articles and the Conep responses to the queries of researchers and CEP members were published.

In 2003, the journal published a response to a question on the criteria characterizing mutilation of human corpses as the result of research, in order to avoid the occurrence of the crimes previously described ${ }^{51}$. Based on the ethical and legal enforcement on the subject established by the Brazilian Penal Code, professor Hilário Veiga de Carvalho, cited by Daniel Romero Muñoz, presented a more detailed orientation on how to carry out research using cadavers: We must do our best to restore the body to its habitual form, disguising the lack of the [anatomical] piece ${ }^{52}$ to avoid the crime of corpse vilification.
Thus, there is no a priori illegality or ethical inadequacy that may lead to mutilation, considering the prior authorization of relatives or, in its absence, of the director of the institution or service in which the research will be carried out. However, one should analyze the type and degree of mutilation to be caused in view of the relevance of the expected results in the study, considering risks and benefits ${ }^{51}$.

This response was corroborated by Muñoz ${ }^{51}$, who is a professor of legal medicine and bioethics at the Medical School of University of São Paulo, based on his professional experience in medical-legal autopsy studies and on Resolution 196/1996 ${ }^{12}$, thus conferring authenticity and reliability to this corpus.

\section{Ethical-legal guidelines for scientific research on corpses}

Based on the cross-sectional analysis of the documents that regulate corpse donation, the information was compiled in guidelines for the ethical, legal and clear performance of researchers (Table 1).

Table 1. Ethical-legal guidelines for researchers for the use of corpses in scientific investigations

1.1) If the body is unclaimed

Check if there is any documentation or identification that facilitates the localization of relatives or legal representatives (Law 8,501/1992 ${ }^{15}$ )

Verify that the death was due to natural causes, since the body cannot be used for research if resulted from a criminal
action (art. 3, $\S 3$, Law $8,501 / 1992^{15}$ ) or it will have to be subjected to a necropsy if the death was due to unnatural
causes (art. $3, \S 2$, Law $8,501 / 1992^{15}$ )
Enable, with the medical school, the publication of edicts with data that might allow the identification of the body by
relatives or legal representatives in local wide-circulation newspapers during 10 alternate days and for a 30 -day period
(art. 2, Law $8,501 / 1992^{15}$ and Chapter XVII, item 96.3 , Provision CG/SP $58 / 1989^{19}$ )
1.2) If the body was identified

Have the declaration of will of the dead person substantiated as "Statement of intent of body donation for study and research purposes" or equivalent (art. 1,857, Civil Code ${ }^{16}$ )

Obtain, in the absence of statement of intent, the consent of the relative or legal representative to validate the corpse donation for research (item IV.6, clause c.2, Resolution CNS 466/2012 ${ }^{17}$ )

Observe the gratuitous and solidary character of the act of disposition of one's own body or the donation by the relatives, being forbidden all types of commercialization (art. 199, §4으. Brazilian Constitution ${ }^{14}$ and art. 14, caput, Civil Code ${ }^{16}$ )

Do not disturb or prevent the funeral to request or coerce relatives to donate the body for research (art. 209, Penal Code ${ }^{13}$ )

Do not violate the burial for the subtraction of the corpse for research (art. 210 and 211, Penal Code ${ }^{13}$ )

1.3) On the authorization of use by the judge of the state court of justice

Check the provision of the Judicial Administrative Department of the state to which the corpse will be donated to follow the procedures for the death register ${ }^{19}$

Request, together with the medical school, the death certificate of the corpse to the civil notary office for the use in studies and research (item 96.2, Chapter XVII, Provision CG/SP 58/1989 ${ }^{19}$ )

Present the originals of the edicts published in wide-circulation newspapers (item 96.3, Chapter XVII, Provision CG/SP $58 / 1989^{19}$ ) to the civil notary office

Await the authorization of the judge of the court of justice for the use of the corpse in research (item 96.4, Chapter XVII, Provision CG/SP 58/1989 ${ }^{19}$ ) 
Table 1. Continuation

1.4) On the submission of the research using corpses to the ethics committee

Analyze the type and degree of mutilation to be caused in the corpse, considering the risks and benefits and the relevance of the expected results for the research project (item III.1, clause b, Resolution CNS 466/2012 ${ }^{17}$ and response from the Conep expert ${ }^{18}$ )

Demonstrate that the risks related to research - that is, the possibility of damage to the physical, psychic, moral, intellectual, social, cultural or spiritual dimension of the person - will be minimized (item II.22, Resolution CNS $466 / 2012^{17}$ )

Submit the research project to the CEP via Plataforma Brasil ${ }^{53}$ (item VI, Resolution CNS 466/2012 ${ }^{17}$ ) after the authorization by the judge of the state court of justice ${ }^{19}$

Observe the general ethical guidelines for conducting research with human beings in Brazil (item I, Resolution CNS $466 / 2012^{17}$ )

1.5) For the research development

Carry out the research with the corpse only after approval of the project by CEP (item X.3, subitem 5, clause a, Resolution CNS 466/2012 ${ }^{17}$ )

Develop the research according to what was outlined in the project approved by CEP (item XI.2, clause c, Resolution CNS 466/2012 ${ }^{17}$ )

Do not destroy parts of the corpse in disagreement with what was approved by CEP (art. 211, Penal Code ${ }^{13}$ )

Do not remove or hide the corpse or its parts for any reason (article 211 , Penal Code ${ }^{13}$ )

Treat the dead body with attitudes, gestures and words of deference and respect during manipulation (art. 12, Civil Code ${ }^{16}$ ), avoiding the occurrence of indemnification of the relatives for damages and losses (art. 12, Civil Code ${ }^{16}$ ) and the crime of corpse vilification (art. 212, Penal Code ${ }^{13}$ )

Maintain the body, as far as possible, in its usual form, reporting in detail all the procedures performed on the corpse, the anatomical parts extracted and the research findings ${ }^{51}$

1.6) After the research is concluded

Enable, together with the medical school, the burial or cremation of the corpse remains that are no longer used for teaching and research purposes (Chapter XVII, item 96.6, Provision CG/SP 58/1989 ${ }^{19}$ )

Communicate to the civil notary office that the body will be buried or cremated by the medical school for proper registration in the death certificate (Chapter XVII, item 96.6, Provision CG/SP 58/1989 ${ }^{19}$ )

Do not disturb or prevent the burial or cremation of corpse remains performed by the medical school (art. 209, Penal Code ${ }^{13}$ )

In addition, from the analysis of the documents that regulate the research using corpses, we elaborated a protocol to be followed by the researcher for the development of an ethical and legal research (Appendix).

\section{Final considerations}

Although corpses have been used for scientific research for centuries, practical concerns about its ethical and legal aspects can be raised. This study presented a protocol that researchers must follow to conduct studies with corpses in Brazil, in accordance with ethical and legal precepts. These guidelines were based on the analysis of the Brazilian corpus on this subject available from 1940 to 2012. Consequently, the researchers will have the assurance that they conducted scientific work with corpses in a legal, clear and ethical way.

Finally, scientific journals should not publish studies that do not follow these precepts, since researchers who do not follow the described protocol may suffer civil, criminal, and administrative penalties for conducting illegal and unethical research.

\section{References}

1. Ghosh SK. Human cadaveric dissection: a historical account from ancient Greece to the modern era. Anat Cell Biol [Internet]. 2015 [acesso 17 jul 2019];48(3):153-69. DOI: 10.5115/ acb.2015.48.3.153

2. Ferreira LM, Hochman B, Barbosa MVJ. Modelos experimentais em pesquisa. Acta Cir Bras [Internet]. 2005 [acesso 17 jul 2019];20(supl 2):28-34. DOI: 10.1590/S0102-86502005000800008

3. Gregory SR, Cole TR. The changing role of dissection in medical education. Jama [Internet]. 2002 [acesso 17 jul 2019];287(9):1180-1. DOI: 10.1001/jama.287.9.1180-JMS0306-4-1 
4. Buonicore GP, Almeida Neto JB, Feijó AGS. A metáfora de um discurso desproporcional diante da análise bioética e jurídico-penal dos delitos de tráfico de órgãos e dos que envolvem o cadáver. In: Loch JA, Souza PVS, organizadores. Bioética na atualidade. Porto Alegre: EdiPUCRS; 2014. p. 69-91.

5. Kim JH. Exposição de corpos humanos: o uso de cadáveres como entretenimento e mercadoria. Mana [Internet]. 2012 [acesso 17 jul 2019];18(2):309-48. DOI: 10.1590/S0104-93132012000200004

6. Richardson R. Death, dissection and the destitute. Chicago: University of Chicago Press; 2000.

7. Bach MC. Still human: a call for increased focus on ethical standards in cadaver research. HEC Forum [Internet]. 2016 [acesso 17 jul 2019];28:355-67. DOI: 10.1007/s10730-016-9309-9

8. Gürses IA, Coşkun O, Gürtekin B, Kale A. The amount of information provided in articles published in clinical anatomy and surgical and radiologic anatomy regarding human cadaveric materials and trends in acknowledging donors/cadavers. Surg Radiol Anat [Internet]. 2016 [acesso 17 ju 2019];38:1225-31. DOI: 10.1007/s00276-016-1684-z

9. Lüdke M, André MEDA. Pesquisa em educação: abordagens qualitativas. São Paulo: EPU; 1986.

10. Gaio R, Carvalho RB, Simões R. Métodos e técnicas de pesquisa: a metodologia em questão. In: Gaio R, organizadora. Metodologia de pesquisa e produção de conhecimento. Petrópolis: Vozes; 2008. p. 147-71.

11. Conselho Nacional de Saúde. Resolução CNS no 1, de 13 de junho de 1988. Aprova as normas de pesquisa em saúde. Diário Oficial da União [Internet]. Brasília, 14 jun 1988 [acesso 17 jul 2019]. Disponível: https://bit.ly/32lsKLv

12. Conselho Nacional de Saúde. Resolução no 196, de 10 de outubro de 1996. Aprova diretrizes e normas regulamentadoras de pesquisas envolvendo seres humanos. Diário Oficial da União [Internet]. Brasília, 16 out 1996 [acesso 17 jul 2019]. Disponível: https://bit.ly/3jd1G6W

13. Brasil. Decreto-lei no 2.848 , de 7 de dezembro de 1940. Código Penal. Diário Oficial da União [Internet]. Rio de Janeiro, 31 dez 1940 [acesso 17 jul 2019]. Disponível: https://bit.ly/391gcKB

14. Brasil. Constituição da República Federativa do Brasil de 1988. Diário Oficial da União [Internet]. Brasília, 5 out 1988 [acesso 17 jul 2019]. Disponível: https://bit.ly/32pQVby

15. Brasil. Lei no 8.501, de 30 de novembro de 1992. Dispõe sobre a utilização de cadáver não reclamado para fins de estudos ou pesquisas científicas e dá outras providências. Diário Oficial da União [Internet]. Brasília, 15 dez 1992 [acesso 17 jul 2019]. Disponível: https://bit.ly/3ewEZr7

16. Brasil. Lei no 10.406, de 10 de janeiro de 2002. Institui o Código Civil. Diário Oficial da União [Internet]. Brasília, 11 jan 2002 [acesso 17 jul 2019]. Disponível: https://bit.ly/391zRKk

17. Conselho Nacional de Saúde. Resolução CNS no 466, de 12 de dezembro de 2012. Aprova diretrizes e normas regulamentadoras de pesquisas envolvendo seres humanos. Diário Oficial da União [Internet]. Brasília, 13 jun 2013 [acesso 17 jul 2019]. Disponível: https://bit.ly/3fBgutZ

18. Cadernos de Ética em Pesquisa [Internet]. Brasília: Comissão Nacional de Ética em Pesquisa. Ano 1 , no 1, 1998 - Ano 6, no 16, 2005 [acesso 16 jul 2020]. Disponível: https://bit.ly/2ChoFxe

19. Corregedoria Geral da Justiça do Estado de São Paulo. Provimento no 58/1989. Normas de serviço: cartórios extrajudiciais [Internet]. São Paulo: CGJ; 1989 [acesso 17 jul 2019]. Disponível: https://bit.ly/3gZODnA

20. Sá-Silva JR, Almeida CD, Guindani JF. Pesquisa documental: pistas teóricas e metodológicas. Rev Bras Hist Ciênc Soc [Internet]. 2009 [acesso 17 jul 2019];1(1):1-15. Disponível: https://bit.ly/32o1Jaj

21. Backes AL, Azevedo DB. A sociedade no parlamento: imagens da Assembleia Nacional Constituinte de 1987/1988. Brasília: Edições Câmara; 2008.

22. Nogueira AM. Assembleia Nacional Constituinte de 1987-88. Fundação Getúlio Vargas [Internet]. c2009 [acesso 17 jul 2019]. Disponível: https://bit.ly/3eE9zyS

23. Brasil. Lei no 9.434, de 4 de fevereiro de 1997. Dispõe sobre a remoção de órgãos, tecidos e partes do corpo humano para fins de transplante e tratamento e dá outras providências. Diário Oficial da União [Internet]. Brasília, 5 fev 1997 [acesso 17 jul 2019]. Disponível: https://bit.ly/3i3udKS

24. Silva JA. Curso de direito constitucional positivo. 37a ed. São Paulo: Malheiros; 2014.

25. Sarlet IW, Marinoni LG, Mitidiero D. Curso de direito constitucional. São Paulo: Editora Revista dos Tribunais; 2013.

26. Brasil. Decreto no 789, de 27 de setembro de 1890. Estabelece a secularisação dos cemitérios. Coleção de Leis do Brasil [Internet]. Rio de Janeiro, 1890 [acesso 16 jul 2020]. Disponível: https://bit.ly/2OtF4kL

27. Brasil. Lei de 16 de dezembro de 1830. Manda executar o Código Criminal. Coleção de Leis do Brasil [Internet]. Rio de Janeiro, 1830 [acesso 17 jul 2019]. Disponível: https://bit.ly/2WpqnU2

28. Brasil. Decreto no 847, de 11 de outubro de 1890. Promulga o Código Penal. Coleção de Leis do Brasil [Internet]. Rio de Janeiro, 13 dez 1890 [acesso 17 jul 2019]. Disponível: https://bit.ly/3j8ZTA3

29. Brasil. Decreto-lei no 3.688, de 3 de outubro de 1941. Lei das contravenções penais. Diário Oficial da União [Internet]. Rio de Janeiro, 3 out 1941 [acesso 17 jul 2019]. Disponível: https://bit.ly/3eA9NXO

30. Mazzilli HN. O crime de violação de sepultura no direito brasileiro. Rev Trib [Internet]. 2009 [acesso 17 jul 2019];98(885):397-424. Disponível: https://bit.ly/32r8jwv

31. Hungria N. Comentários ao código penal. Rio de Janeiro: Forense; 1959.

32. David DF. Análise crítica dos crimes contra o respeito aos mortos no direito penal brasileiro. Rev Bras Ciênc Crim [Internet]. 2015 [acesso 17 jul 2019];117:141-73. p. 145. Disponível: https://bit.ly/30f7t3m

33. David DF. Op. cit. 
34. Conselho Nacional de Justiça. Enunciado no 37 [Internet]. In: Enunciados aprovados na I Jornada de Direito da Saúde do Conselho Nacional de Justiça; 15 maio 2014; São Paulo. São Paulo: CNJ; 2014 [acesso 7 ago 2020]. Disponível: https://bit.ly/3fl1Lgc

35. Brasil. Decreto no 9.175, de 18 de outubro de 2017. Regulamenta a Lei no 9.434, de 4 de fevereiro de 1997, para tratar da disposição de órgãos, tecidos, células e partes do corpo humano para fins de transplante e tratamento. Diário Oficial da União [Internet]. Brasília, 19 out 2017 [acesso 17 jul 2019]. Disponivel: https://bit.ly/2Ci4wak

36. Sociedade Brasileira de Anatomia. Entendendo a doação de corpos para fins de ensino e pesquisa [Internet]. [s.d.] [acesso 17 jul 2019]. Disponível: https://bit.ly/3jdJpX8

37. Moraes MCB, Konder C . Art. 14. In: Aguiar RR Jr, coordenador. IV Jornada de Direito Civil [Internet]. Brasília: Conselho da Justiça Federal; 2007 [acesso 17 jul 2019]. v. 1. p. 76-9. Disponivel: https://bit.ly/3hbbUTP

38. Pimentel W, Sarsur M, Dadalto L. Autonomia na doação de órgãos post mortem no Brasil. Rev. bioét. (Impr.) [Internet]. 2018 [acesso 17 jul 2019];26(4):530-6. DOI: 10.1590/198380422018264271

39. Brasil. Projeto de lei no 3.643/2019. Altera o caput do art. 40 da Lei $n=9.434$, de 4 de fevereiro de 1997, a fim de tornar explícito que o consentimento familiar, no caso de doação de órgãos, tecidos e partes do corpo humano para depois da morte, só se faz necessário quando o potencial doador não tenha, em vida, se manifestado expressa e validamente a respeito. Câmara dos Deputados [Internet]. Brasília, 18 jun 2019 [acesso 3 ago 2020]. Disponível: https://bit.ly/3gqPyxo

40. Tartuce F. Manual de direito civil. 2a ed. São Paulo: Método; 2011.

41. Moraes MCB, Konder C. Art. 11. In: Aguiar RR Jr, coordenador. Op. cit. p. 62-4. Disponível: https://bit.ly/30moLeS

42. Paul ACLG. Art. 11. In: Aguiar RR Jr, coordenador. Op. cit. p. 60-2. Disponível: https://bit.ly/2Civxuf

43. Régis MLD. Art. 11. In: Aguiar RR Jr, coordenador. Op. cit. p. 64-5. Disponível: https://bit.ly/2Cmfz26

44. Almeida Neto JB, Feijó AGS, Loch JA, Bilhalva GV, Baú MK. O valor social do cadáver humano: personalidade, pesquisa científica, doação de órgãos e corpos. Direito Justiça [Internet]. 2008 [acesso 17 jul 2019];34(1):60-73. Disponível: https://bit.ly/3eDeUGN

45. Barreto WP. Art. 11. In: Aguiar RR Jr, coordenador. Op. cit. p. 66-8. Disponível: https://bit.ly/2ZCKVL0

46. Marques Filho J. Ética em pesquisa: dez anos da Resolução CNS 196/96. Rev Bras Reumatol [Internet]. 2007 [acesso 17 jul 2019];47(1):2-3. DOI: 10.1590/S0482-50042007000100002

47. Hossne WS. Poder e injustiça na pesquisa com seres humanos. In: Garrafa V, Pessini L, organizadores. Bioética: poder e injustiça. São Paulo: Loyola; 2004. p. 271-86.

48. Conselho Nacional de Saúde. Manual operacional para comitês de ética em pesquisa [Internet]. 4a ed. rev. atual. Brasília: Ministério da Saúde; 2006 [acesso 17 jul 2019]. Disponível: https://bit.ly/2Wm5NEb

49. Brasil. Ministério da Saúde. CEP por macrorregiões [Internet]. Brasília: Conep; 2018 [acesso 17 jul 2019]. Disponível: https://bit.ly/2Wra894

50. Escolas Médicas do Brasil. Estatísticas nacionais [Internet]. [s.d.] [acesso 17 jul 2019]. Disponível: https://bit.ly/2ZAuOh1

51. Muñoz DR. A Conep responde. Cad Ética Pesqui [Internet]. 2003 [acesso 17 jul 2019];6(12):12-4. Disponível: https://bit.ly/2CLU4aP

52. Muñoz DR. Op. cit. p. 13.

53. Brasil. Ministério da Saúde. Plataforma Brasil [Internet]. [s.d.] [acesso 16 jul 2020]. Disponível: https://bit.ly/3947Xxf

\section{Participation of the authors}

The authors contributed equally to the manuscript.

\section{Correspondence}

Patricia Melo Bezerra - Rua Palmeiras, 5, Campestre CEP 09070-400. Santo André/SP, Brasil.

Patricia Melo Bezerra - PhD - patriciamelobe@gmail.com

(iD) 0000-0003-3667-5504

Marina de Neiva Borba - PhD - marina.borba@usp.br

(iD) 0000-0002-4685-1172

lara Coelho Zito Guerriero - PhD - iara.guerriero1@gmail.com

(iD) 0000-0001-7381-5516

Sueli Gandolfi Dallari - Associate professor - sdallari@uol.com.br

iD 0000-0002-6999-4854 


\section{Appendix}

\section{Ethical-legal protocol for the use of corpses in scientific research in Brazil}

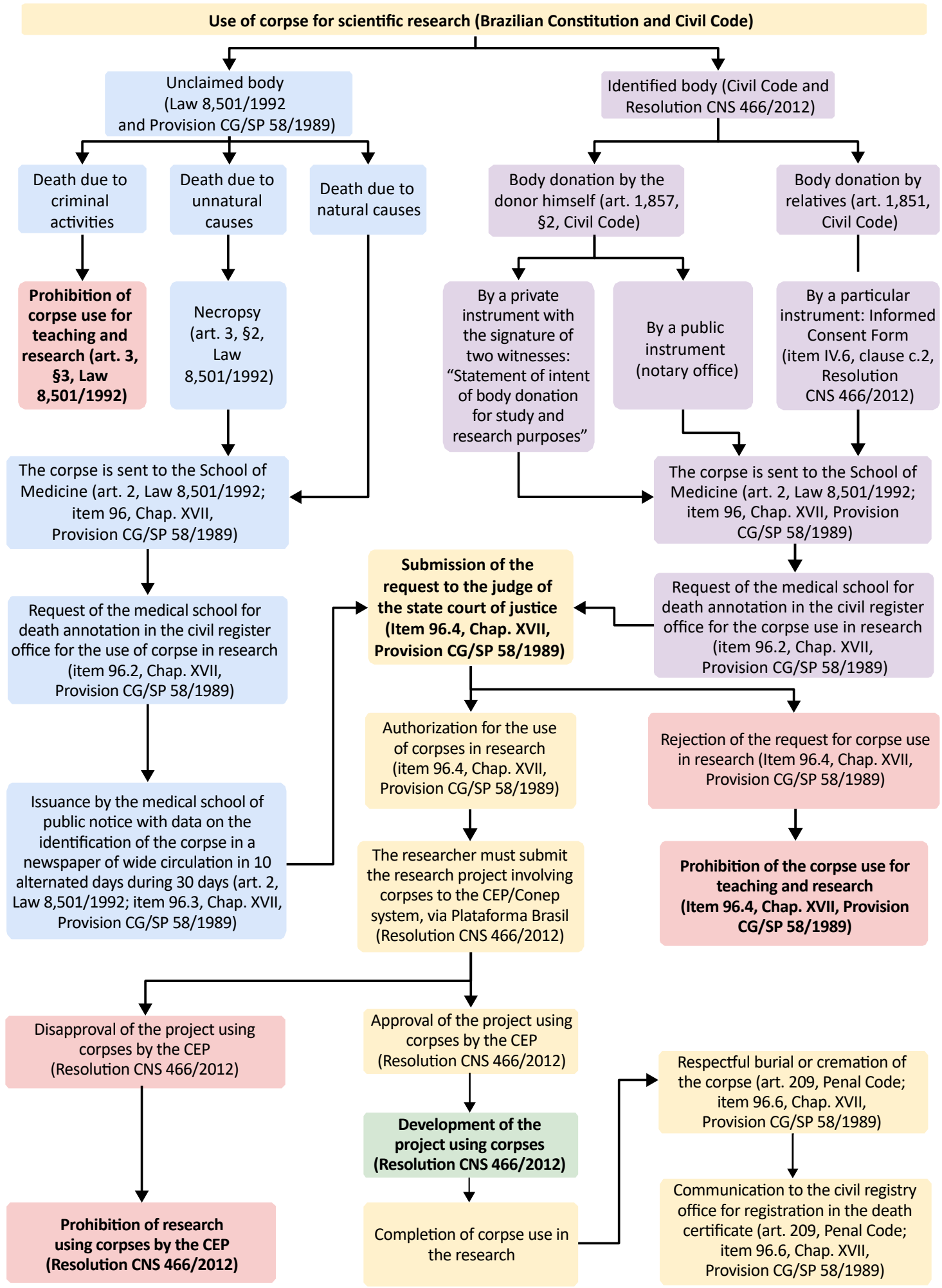

